\title{
Removal efficiency and mechanism of bio-treated coking wastewater by catalytic ozonation using $\mathrm{MnO}_{2}$ modified with anionic precursors
}

\author{
Jie Zhang ${ }^{1}$, Ben Dong ${ }^{1}$, Ding Ding ${ }^{2}$, Shilong $\mathrm{He}^{1}$, Sijie $\mathrm{Ge}^{\mathrm{1}^{+}}$ \\ ${ }^{1}$ School of Environment Science and Spatial Informatics, China University of Mining and Technology, Xuzhou 221116, Jiangsu Province, PR China \\ ${ }^{2}$ SunRui Marine Environment Engineering Company, Qingdao 266101, Shandong Province, PR China
}

\begin{abstract}
In this paper, $\mathrm{MnO}_{2}$ catalyst were firstly prepared and modified by four kinds of anionic precursors (i.e., $\mathrm{NO}_{3}^{-}, \mathrm{AC}^{-}, \mathrm{SO}_{4}^{2-}$ and $\mathrm{Cl}^{-}$) through redox precipitation method. After that, bio-treated coking wastewater (BTCW) was prepared and employed as targeted pollutants to investigate the catalytic ozonation performance of prepared- $\mathrm{MnO}_{2}$ catalyst was investigated and characterized by the removal efficiencies and mechanism of the prepared bio-treated coking wastewater (BTCW), which was employed as the targeted pollutants. Specifically, the effects of specific surface area, crystal structure, valence state of $\mathrm{Mn}$ element and lattice oxygen content on catalytic activity of $\mathrm{MnO}_{2}$ materials were characterized by BET, XRD and XPS, respectively. Results showed that COD of BTCW could be removed $47.39 \%$ under $\mathrm{MnO}_{2}-\mathrm{NO}_{3}{ }^{-}$catalyst with $2 \mathrm{~h}$ reaction time, which was much higher than that of $\mathrm{MnO}_{2}-\mathrm{AC}^{-}(3.94 \%), \mathrm{MnO}_{2}-\mathrm{SO}_{4}{ }^{2-}(12.42 \%), \mathrm{MnO}_{2}-\mathrm{Cl}^{-}(12.94 \%)$ and pure $\mathrm{O}_{3}$ without catalyst $(21.51 \%)$, respectively. So, $\mathrm{MnO}_{2}-\mathrm{NO}_{3}^{-}$presented the highest catalytic performance among these catalysts. The reason may be attributed to a series of better physiochemical properties including the smaller average grain, the larger specific surface area and active groups, more crystal defect and oxygen vacancy, higher relative content of $\mathrm{Mn}^{3+}$ and adsorbed oxygen $\left(\mathrm{O}_{\mathrm{ads}}\right)$ than that of another three catalysts.
\end{abstract}

Keywords: Anionic precursors, Bio-treated coking wastewater, $\mathrm{MnO} 2$ catalyst, Ozonation

\section{Introduction}

Advanced oxidation processes (AOPs) that utilized free-radical reactions are considered as an effective and promising method for the degradation and mineralization refractory organic compounds in wastewater treatment. Many studies have been conducted on the degradation persistent organic compounds by AOPs technologies, such as photocatalysis process [1, 2], Fenton of Fenton-like oxidation [3, 4], ozonation [5, 6] and non-thermal plasma [7]. Among them, heterogeneous catalytic ozonation technology has been widely studied because they can generate more reactive oxygen species (ROS) to ensure highly efficient in degrading the refractory organic contaminants in wastewater. Among them, heterogeneous catalytic ozonation technology has been widely studied because they can generate more reactive oxygen species (ROS) to ensure highly efficient in degrading the refractory organic contaminants in waste- water [8-10]. Among heterogeneous catalytic ozonation technologies, catalytic ozonation using $\mathrm{MnO}_{2}$ catalyst has been widely used in wastewater treatment with the characteristics of complex composition, high organic matter concentration and recalcitrance [11-13]. In particular, Manganese dioxide $\left(\mathrm{MnO}_{2}\right)$ has its advantages, such as unique $\mathrm{Mn}^{2+} / \mathrm{Mn}^{3+}$ redox cycle involving a single electron transfer, environmental friendliness and diverse crystallographic structure, which may help $\mathrm{MnO}_{2}$ been extensively developed for applications in heterogeneous catalytic ozonation technologies to produce active radicals [14-16]. Obviously, catalysts play a significant role in catalytic ozonation. Refractory organic pollutants could be efficiently degraded by $\mathrm{MnO}_{2}$ based catalyst owning the excellent physical and chemical properties. Some studies indicated that different preparation conditions have a certain effect on the catalytic performance of the catalyst, such as acid treatment [17], reactant ratio, reaction time and temperature [18], calcination time
This is an Open Access article distributed under the terms of the Creative Commons Attribution Non-Commercial License (http://creativecommons.org/licenses/by-nc/3.0/) which permits unrestricted non-commercial use, distribution, and reproduction in any medium, provided the original work is properly cited.

Copyright (C) 2021 Korean Society of Environmental Engineers
Received July 15, 2020 Accepted September 14, 2020

${ }^{\dagger}$ Corresponding author

Email: gesijie@cumt.edu.cn

Tel: +86516 83591315

ORCID: 0000-0002-7920-5038 
and temperature, precursor anions, etc. Although the precursor anions did not change the elemental composition of the $\mathrm{MnO}_{2}$ catalyst, it would largely affect the structural characteristics of the $\mathrm{MnO}_{2}$ catalyst and then generate different catalytic performance. Jung et al. [19] used various $\mathrm{Mn}^{2+}$ precursors to prepare $\mathrm{MnO}_{2}$ by a simple redox method, which were used to investigate the influence of Mn-precursors in the CO oxidation. The catalytic performance was arranged from high to low as: $\mathrm{MnO}_{2}-\mathrm{SO}_{4}{ }^{2-}, \mathrm{MnO}_{2}-\mathrm{AC}^{-}, \mathrm{MnO}_{2}-\mathrm{NO}_{3}^{-}, \mathrm{MnO}_{2}-\mathrm{Cl}^{-}$. Hwang et al. [20] used manganese nitrate and manganese acetate to prepare $\mathrm{MnO}_{2} / \mathrm{TiO}_{2}$ catalysts through a sol-gel method, concluding that the catalysts synthesized with manganese acetate showed high catalytic performance as a result of abundant $\mathrm{MnO}_{2}$ species and strong acid sites. Yue Yu, et al. [21] used manganese acetate, manganese nitrate, manganese chloride and manganese sulfate to prepare $\mathrm{MnO}_{2}$ catalysts on the toluene oxidation. The catalytic performance was arranged from high to low as: $\mathrm{MnO}_{2}-\mathrm{AC}^{-}$, $\mathrm{MnO}_{2}-\mathrm{NO}_{3}{ }^{-}, \mathrm{MnO}_{2}-\mathrm{Cl}^{-}, \mathrm{MnO}_{2}-\mathrm{SO}_{4}{ }^{2-}$, which resulted in $\mathrm{MnO}_{2}-\mathrm{AC}$ owned potential for practical applications. Pena et al. [22] observed that catalysts prepared using manganese nitrate yielded $\mathrm{MnO}_{2}$ and displayed enhanced catalytic performance than the corresponding catalyst prepared with manganese acetate. In fact, there remains on-going debate over how catalytic activity is influenced by the active phase of Mn-based catalysts prepared with different precursors. However, it is still unclear that the Bio-treated coking wastewater (BTCW) are degraded by catalytic ozonation using $\mathrm{MnO}_{2}$ catalyst modified with anionic precursors. So, it is interesting to know that the reaction mechanism and removal performance of BTCW is catalyzed by different $\mathrm{MnO}_{2}$ catalyst modified with anionic precursors.

BTCW removal has been widely studied by catalytic ozonation due to the characteristics of strong toxicity, structural stability and low concentration of organic matter [23]. Liu et al. [24] synthesized a kind of $\mathrm{CuFe}_{2} \mathrm{O}_{4}$ nanocomposite as catalyst to investigate and evaluate the feasibility of the catalytic ozonation for the treatment of biologically treated coking wastewater. Their results showed that the total organic carbon removal efficiency in the catalytic ozonation was 2.9 times higher than that in the uncatalyzed ozonation. Zhang et al. [25] prepared different kinds of zinc ferrite catalysts for ozonation of BTCW, which showed that the presence of catalysts also generated a high removal efficiency for BTCW compared to non-catalytic ozonation, and the performance of the catalysts was primarily determined by their synthesis method defining the surface properties. However, few researchers studied the catalytic performance and mechanism of ozonation of BTCW with different precursors of manganese dioxide.

In this study, BTCW was selected as the target pollutant in this study, four kinds of $\mathrm{MnO}_{2}$ catalysts were synthesized from various $\mathrm{Mn}^{2+}$ precursors of manganese chloride, manganese nitrate, manganese acetate and manganese sulfate by redox precipitation method. Moreover, based on evaluating the catalytic performance of four $\mathrm{MnO}_{2}$ catalysts in the process of ozone oxidation for removal of bio-refractory organic pollutants in BTCW, the role mechanisms of different precursors on catalytic activities will be analyzed by XRD, TEM, BET and XPS, respectively.

\section{Experimental}

\subsection{Synthesis of Catalyst}

The reagents and chemicals were of analytical grade and purchased from national drug chemical reagents Co. Ltd (China). The redox-precipitation method is a typical catalyst preparation method by liquid phase preparation process for manganese-based catalyst, which has the advantages of simple preparation procedure and mild reaction conditions and thus has been becoming the research hotspot in recent years [21]. So, the redox-precipitation method is employed and selected as the synthetic method for $\mathrm{MnO}_{2}$ based catalysts in this study. Furthermore, the structure defects and the crystallinity of the catalyst can be controlled and improved its performance by changing the preparation conditions such as choice of reactant precursor, reactant ratio, $\mathrm{pH}$, reaction time, temperature and calcination time, respectively [21, 26, 27]. Therefore, the above preparation conditions need to be comprehensively considered to manipulate the synthetic process of catalysts. The preparation process of four $\mathrm{MnO}_{2}$ catalysts are showed as follows. Firstly, $100 \mathrm{~mL}(0.45 \mathrm{~mol} / \mathrm{L})$ of solution A (manganese nitrate solution, manganese acetate solution, manganese sulfate solution or manganese chloride solution) was added dropwise into $75 \mathrm{~mL}(0.2 \mathrm{~mol} / \mathrm{L})$ of solution B (potassium permanganate solution, $\mathrm{KMnO}_{4}$ ), which was stirred magnetically for $15 \mathrm{~min}$. After that, ammonia was used to adjust the $\mathrm{pH}$ of the mixture to 1.5. After crystallizing for $11 \mathrm{~h}$, the product was collected by filtration and fully rinsed several times with deionized water to remove the remaining $\mathrm{KMnO}_{4}$. Finally, the collecting production were dried for $13 \mathrm{~h}$ at $105^{\circ} \mathrm{C}$ in the oven and calcined at $400^{\circ} \mathrm{C}$ for $4.5 \mathrm{~h}$ in the tubular furnace, and the catalysts denoted as $\mathrm{MnO}_{2}-\mathrm{SO}_{4}{ }^{2-}, \mathrm{MnO}_{2}-\mathrm{AC}$, $\mathrm{MnO}_{2}-\mathrm{Cl}^{-}$and $\mathrm{MnO}_{2}-\mathrm{NO}_{3}^{-}$were obtained, which were used to carry the oxidizing experiments and characteristic analysis, respectively.

\subsection{Characterization of Catalysts}

The atomic arrangement inside the crystal was determined by X-ray powder diffraction (model: D8 ADVANCE, Bruker, Germany). The $\mathrm{XRD}$ had monochromatic radiation $\mathrm{Cu}-\mathrm{K} \alpha$ as the source of X-rays and operates at $40 \mathrm{kV}, 30 \mathrm{~mA}$. The surface compositions of the catalysts were determined by x-ray photoelectron spectroscopy (XPS), which was performed with ESCALAB250Xi system equipped with an Al-Ka excitation source and operated at $15 \mathrm{~kW}$ and 1486.6 $\mathrm{eV}$. The spectra were fitted with Casa XPS software. Charging effects were corrected by adjusting the binding energy of C $1 \mathrm{~s}$ to $284.8 \mathrm{eV}$.

\subsection{Catalyst Activity Test}

The catalytic ozonation treatment of simulated BTCW was performed in a semi-batch reactor showed in Fig. S1. The fixed reactor adopted a double-layer design and the inner layer was the catalytic ozonation reaction layer fed with $1 \mathrm{~L}$ aqueous solution. The constant temperature of water bath pot was used to keep the stable temperature of the inner layer reaction. Ozone was generated by ozone generator (COM-AD-01, Germany) from oxygen with high purity. During the reaction, the gaseous ozone was fed through a porous diffuser at the bottom of the reactor with a flow rate of $2.0 \mathrm{~L} / \mathrm{min}$ and the concentration of $2.6 \mathrm{mg} / \mathrm{L}$. The tail gas produced in the experiment was absorbed by potassium iodide solution. In the 
typical catalytic ozonation procedure, $2 \mathrm{~g}$ catalyst was mixed with $1 \mathrm{~L}$ simulated BTCW (cyclohexanone: aniline $=20: 1, \mathrm{pH}=7.2$, $323 \pm 1 \mathrm{~K}$; the initial COD was $470 \mathrm{mg} / \mathrm{L}$ ) in the reaction system. During the reaction process, the samples were taken to analyze at certain intervals.

\section{Results and Discussion}

\subsection{Catalytic Ozonation Performances}

The degradation performance of BTCW by ozonation and catalytic ozonation is showed in Fig. 1. Compared with the alone ozonation process, it can be observed that the degradation rates of BTCW are greatly improved with the addition of the prepared-catalysts. The degradation rates are accordingly increased about $8.57 \%$, $9.09 \%, \quad 17.57 \%$ and $21.51 \%$, respectively when $\mathrm{MnO}_{2}-\mathrm{Cl}^{-}$, $\mathrm{MnO}_{2}-\mathrm{SO}_{4}{ }^{2-}, \mathrm{MnO}^{2}-\mathrm{AC}^{-}$and $\mathrm{MnO}_{2}-\mathrm{NO}_{3}{ }^{-}$are employed as the catalysts to enhance the ozonation efficiency on BTCW. The difference may be due to the different morphology and distribution of active components formed on the catalyst surface after calcination of different precursors. The catalytic reaction mechanism will be further discussed in part 3.2 through part 3.5. Reaction kinetics of four prepared-catalysts were further investigated to the catalytic ozonation performance. The mathematic equation of pseudo first-order and second-order kinetic model could be expressed as Eq. (1) and Eq. (2), respectively.

$$
\begin{aligned}
& -\operatorname{Ln}\left(C_{t} / C_{0}\right)=K_{1} t \\
& \mathrm{C}_{0} / C_{t}=K_{2} C_{0} t+1
\end{aligned}
$$

Where $K_{1}$ is the pseudo first-order rate constant $\left(\mathrm{min}^{-1}\right)$; $\mathrm{K}_{2}$ is the pseudo second-order rate constant $\left((\mathrm{mg} / \mathrm{L})^{-1} \mathrm{~min}^{-1}\right)$; $t$ represents the reaction time; $\mathrm{C}_{0}$ and $\mathrm{C}_{\mathrm{t}}$ stand for the COD concentration at $0 \mathrm{~min}$ and $\mathrm{t} \min$, respectively.

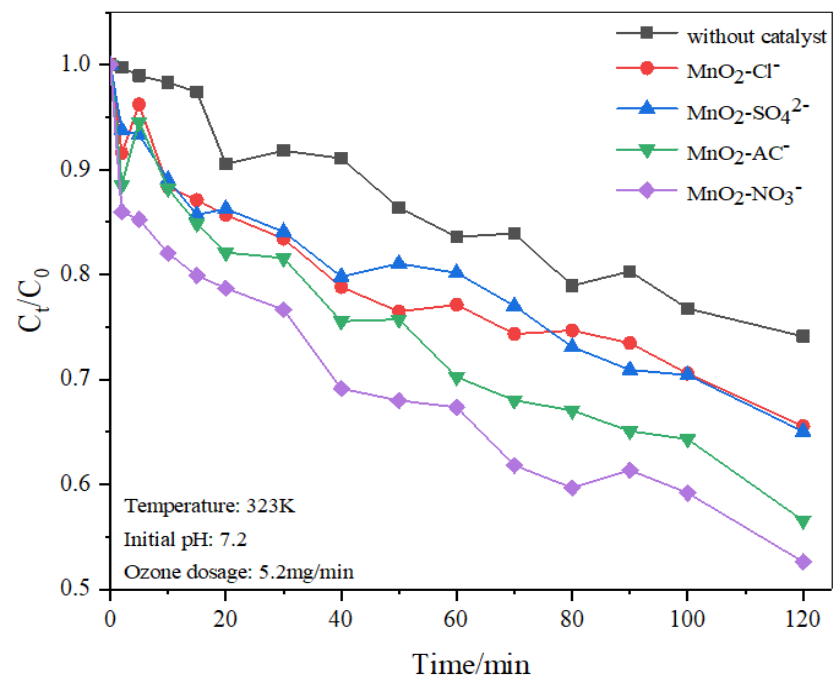

Fig. 1. BTCW degradation performance by four prepared-catalysts and without catalyst.
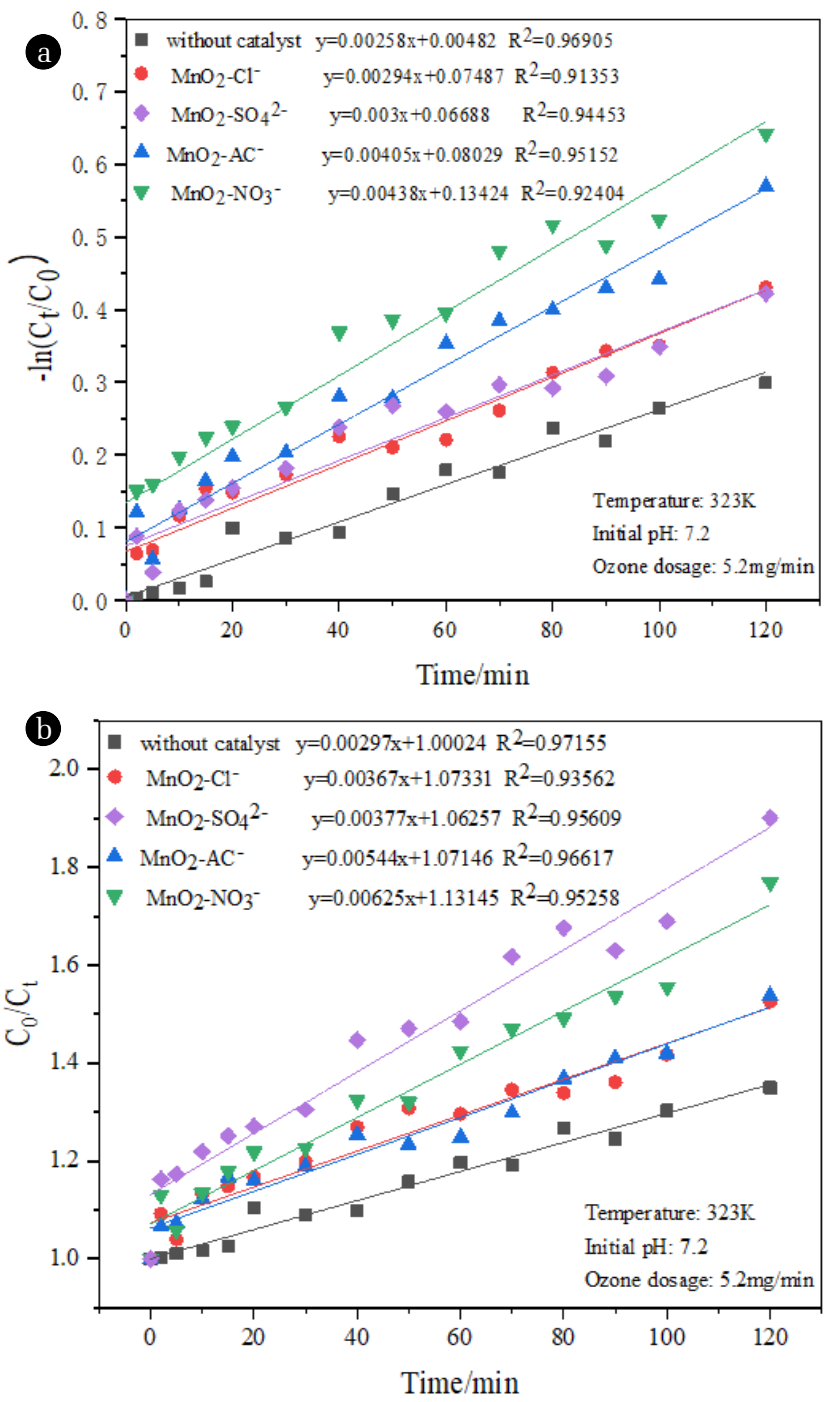

Fig. 2. The fitting curves of pseudo first-order (a) and pseudo second-order (b) reaction kinetics for different ozonation.

The fitting curves and kinetic parameters of pseudo first-order and pseudo second-order reaction kinetics for different ozonation are showed in Fig. 2(a), (b) and Table S1. As showed in Table $\mathrm{S} 1$, the linear correlation coefficient $\mathrm{R}^{2}$ of the second-order reaction kinetics was significantly higher than that of the first-order reaction kinetics. Therefore, under the condition of ozonation and catalytic ozonation, the degradation process of BTCW was more in line with the pseudo second-order reaction kinetics. Fig. 2(b) and Table S1 show that the rate constants $\left(\mathrm{K}_{2}\right)$ of catalytic ozonation of $\mathrm{MnO}_{2}-\mathrm{Cl}^{-}, \mathrm{MnO}_{2}-\mathrm{SO}_{4}{ }^{2-}, \mathrm{MnO}^{2}-\mathrm{AC}^{-}$and $\mathrm{MnO}_{2}-\mathrm{NO}_{3}{ }^{-}$ were calculated to be $0.00297,0.00367,0.00377,0.00544$ and $0.00625(\mathrm{mg} / \mathrm{L})^{-1} \mathrm{~min}^{-1}$, respectively. The kinetic rate of $\mathrm{MnO}_{2}-\mathrm{NO}_{3}{ }^{-}$catalyst are almost two times of ozonation without catalyst. To sum up, four kinds of prepared-catalysts have different catalytic ozonation performance and nitrate modified $\mathrm{MnO}_{2}$ (i.e., $\mathrm{MnO}_{2}-\mathrm{NO}_{3}{ }^{-}$) has the highest catalytic ozonation activity on BTCW. 


\subsection{Specific Surface and Pore size Distribution}

The results of BET surface area for different catalysts are showed in Table 1. Compared with the other three catalysts, $\mathrm{MnO}_{2}-\mathrm{NO}_{3}{ }^{-}$ catalyst has the highest specific surface area, which is about 9 times of $\mathrm{MnO}_{2}-\mathrm{Cl}^{-}$catalyst and thus $\mathrm{MnO}_{2}-\mathrm{NO}_{3}{ }^{-}$catalyst has the best catalytic activities. Moreover, the total pore volume of $\mathrm{MnO}_{2}-\mathrm{NO}_{3}^{-}$is also the highest among the four different $\mathrm{MnO}_{2}$ catalysts, which is beneficial to the adsorption and then increases the mass transfer rate between catalyst and BTCW [28]. So, the highest kinetic and removal rate through $\mathrm{MnO}_{2}-\mathrm{NO}_{3}{ }^{-}$catalyst are observed in Fig. 1 and Fig. 2, respectively.

Table 1. Specific Surface Area and Pore Volume of Four Prepared-MnO2 Catalysts

\begin{tabular}{lcc}
\hline Catalyst & $\begin{array}{c}\text { Specific surface area } \\
\left(\mathbf{m}^{2} / \mathbf{g}\right)\end{array}$ & $\begin{array}{c}\text { Pore volume } \\
\left(\mathbf{c m}^{3} / \mathbf{g}\right)\end{array}$ \\
\hline $\mathrm{MnO}_{2}-\mathrm{SO}_{4}{ }^{2-}$ & 39.570 & 0.0035 \\
$\mathrm{MnO}_{2}-\mathrm{AC}^{-}$ & 115.428 & 0.0097 \\
$\mathrm{MnO}_{2}-\mathrm{Cl}^{-}$ & 14.683 & 0.0013 \\
$\mathrm{MnO}_{2}-\mathrm{NO}_{3}^{-}$ & 132.303 & 0.0105 \\
\hline
\end{tabular}

\subsection{Crystal Phase}

In order to analyze the crystalline structure of the different $\mathrm{MnO}_{2}$ catalysts, the XRD studies were carried out in this section. The XRD patterns of $\mathrm{MnO}_{2}$ prepared by different precursor anions $\left(\mathrm{NO}_{3}{ }^{-}\right.$, $\left.\mathrm{AC}, \mathrm{SO}_{4}{ }^{2-}, \mathrm{Cl}^{-}\right)$are presented in Fig. 3. The $\mathrm{MnO}_{2}-\mathrm{SO}_{4}{ }^{2-}$ and $\mathrm{MnO}_{2}-\mathrm{Cl}^{-}$ catalyst have the characteristic diffraction peaks at around $2 \theta=$ $28.2^{\circ}, 37.5^{\circ}, 42.9^{\circ}$ and $56.7^{\circ}$, and these diffraction peaks are assigned to the (110), (101) and (211) reflections of $\beta-\mathrm{MnO}_{2}$ (JCPDS No.24-0735 or JCPDS No.81-2261). The $\mathrm{MnO}_{2}-\mathrm{NO}_{3}{ }^{-}$catalyst has the diffraction peaks at around $2 \theta=37.7^{\circ}, 42.8^{\circ}$ and $56.9^{\circ}$, and these diffraction peaks are assigned to the (101), (111) and (211) reflections of $\beta-\mathrm{MnO}_{2}$ (JCPDS No.24-0735 or JCPDS No.81-2261). The $\mathrm{MnO}_{2}$-AC catalyst has characteristic diffraction peaks at around $2 \theta=12.9^{\circ}, 18.2^{\circ}, 28.6^{\circ}, 37.4^{\circ}$ and these diffraction peaks are assigned to the (110), (200), (310), (121) and (301) reflections of $\alpha-\mathrm{MnO}_{2}$ (JCPDS No.44-0141 or JCPDS No.72-1982). From the above XRD results, it can be seen that the different anions affect the crystallization and phase transition of catalysts to some extent [21].

According to the principle of Voigt single line method [29], the average size and lattice distortion of $\mathrm{MnO}_{2}$ grain could be calculated from the diffraction peak parameters of the crystal plane. The calculation results are showed in Table 2. The average grain size of $\mathrm{MnO}_{2}$ material was arranged from high to low as: $\mathrm{MnO}_{2}-\mathrm{Cl}^{-}$, $\mathrm{MnO}_{2}-\mathrm{SO}_{4}{ }^{2-}, \mathrm{MnO}_{2}-\mathrm{AC}, \mathrm{MnO}_{2}-\mathrm{NO}_{3}{ }^{-}$, and the micro strain capacity was arranged from high to low as: $\mathrm{MnO}_{2}-\mathrm{NO}_{3}^{-}, \mathrm{MnO}_{2}-\mathrm{AC}^{-}$, $\mathrm{MnO}_{2}-\mathrm{SO}_{4}{ }^{2-}, \mathrm{MnO}_{2}-\mathrm{Cl}^{-}$. Some studies indicated that the crystal defect was the main cause of lattice distortion, which might promote the migration of adsorbed oxygen, and the migration of adsorbed oxygen played an important role in the decomposition and transformation of organic matter, and finally affected the catalytic performance of the catalyst [30, 31]. Therefore, although all the four $\mathrm{MnO}_{2}$ materials have some crystal defects, the $\mathrm{MnO}_{2}-\mathrm{NO}_{3}^{-}$catalyst has the smallest grain size and the largest lattice distortion, which might be also a reason that this catalyst has the best catalytic activities in the process of ozonation for removing organic pollutants.

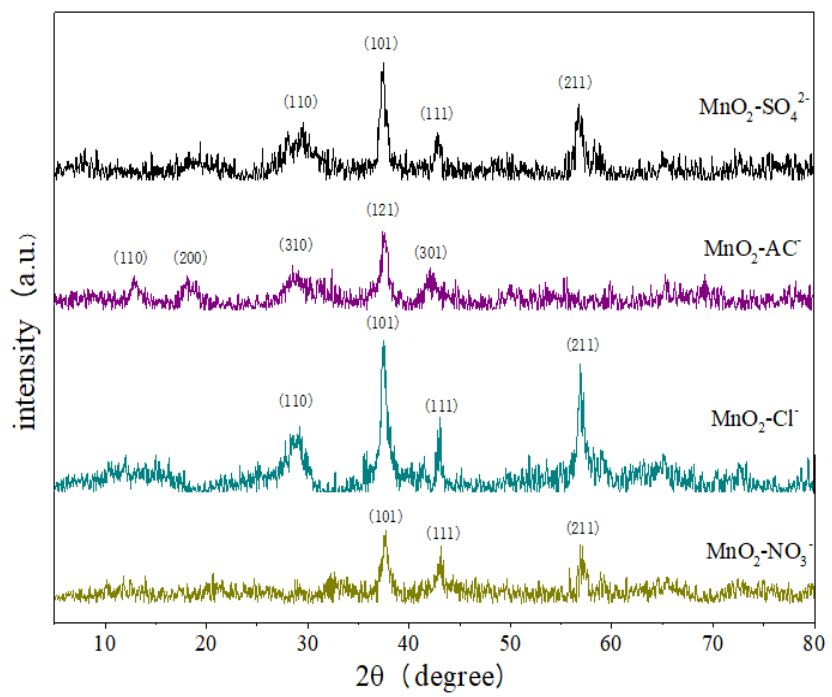

Fig. 3. XRD patterns of different $\mathrm{MnO} 2$ catalysts prepared by different precursor anions.

Table 2. Grain size and lattice distortion of different $\mathrm{MnO} 2$ catalysts

\begin{tabular}{lcc}
\hline Catalyst & Grain size $(\mathbf{n m})$ & Lattice distortion \\
\hline $\mathrm{MnO}_{2}-\mathrm{SO}_{4}{ }^{2-}$ & 14.5 & $7.567 \times 10^{-3}$ \\
$\mathrm{MnO}_{2}-\mathrm{AC}^{-}$ & 12.6 & $8.6526 \times 10^{-3}$ \\
$\mathrm{MnO}_{2}-\mathrm{Cl}^{-}$ & 15.2 & $7.190 \times 10^{-3}$ \\
$\mathrm{MnO}_{2}-\mathrm{NO}_{3}^{-}$ & 11.9 & $9.151 \times 10^{-3}$ \\
\hline
\end{tabular}

\subsection{Surface Chemical Compositions}

Oxygen vacancy is one of the most common crystal defects, which has significant influence on the catalytic ozonation performance of $\mathrm{MnO}_{2}$ materials. The presence of $\mathrm{Mn}^{3+}$ on the surface of $\mathrm{MnO}_{2}$ material is an important reason for the occurrence of oxygen vacancy, and its reaction mechanism is showed as follows [32]:

$$
-\mathrm{Mn}^{4+}-\mathrm{O}^{2-}-\mathrm{Mn}^{4+}-\rightarrow-\mathrm{Mn}^{3+}-\Delta-\mathrm{Mn}^{3+}-+\frac{1}{2} \mathrm{O}_{2}
$$

Where $\Delta$ represents oxygen vacancy, so a higher $\mathrm{Mn}^{3+}$ relative content indicates that there are more oxygen vacancies in $\mathrm{MnO}_{2}$ material.

In order to analyze the influence of four precursor anions on the valence state of $\mathrm{Mn}$ on the surface of $\mathrm{MnO}_{2}$, Peak-splitting fitting was performed on energy spectrum (narrow sweep) of four $\mathrm{MnO}_{2}$ materials through XPS PEAK41. Fig. 4(a) illustrated Mn 2p XPS spectra of $\mathrm{MnO}_{2}$ prepared by different precursor anions. Due to existing a fixed energy interval and peak area ratio between $\mathrm{Mn} 2 \mathrm{p}_{1 / 2}$ and $\mathrm{Mn} 2 \mathrm{p}_{3 / 2}$ in $\mathrm{MnO}_{2}$, in this article, only $\mathrm{Mn} 2 \mathrm{p}_{3 / 2}$ was analyzed in detail. It could be seen from Fig. 4(a) that $\mathrm{MnO}_{2}$ materials prepared by four anions could be divided into two characteristic 

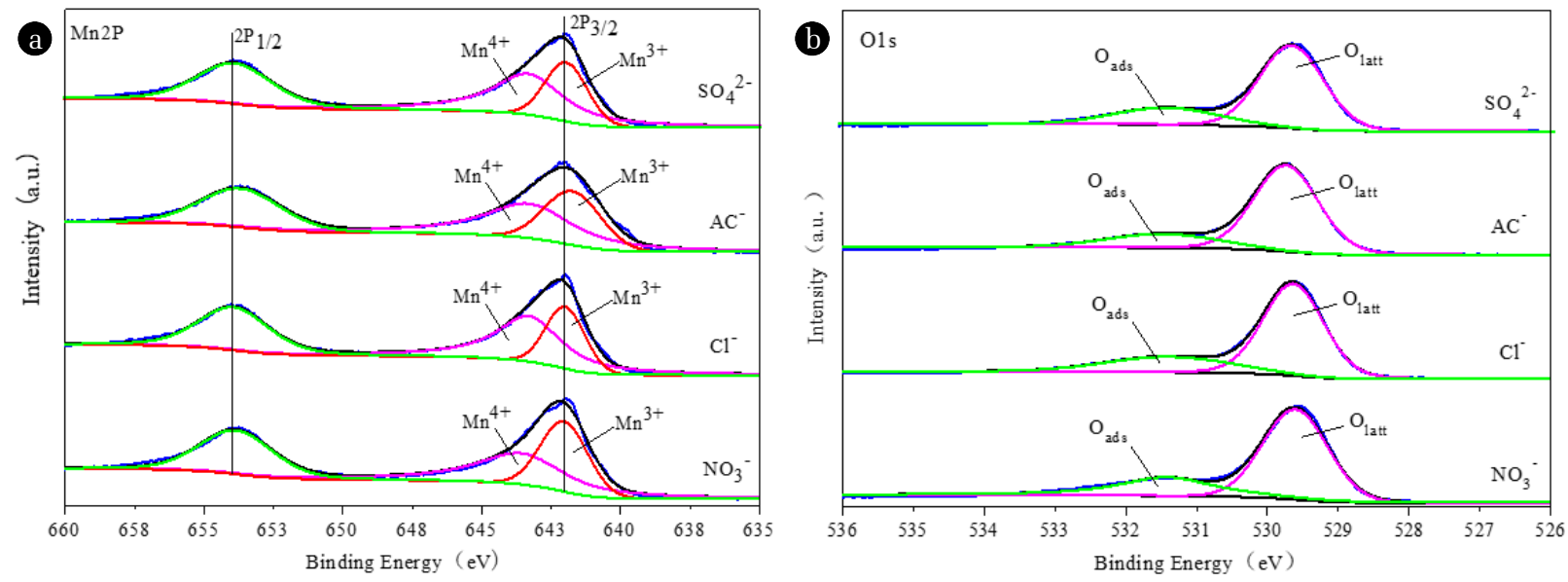

Fig. 4. (a) The $\mathrm{Mn} 2 \mathrm{P}$ and (b) O1s XPS spectra of $\mathrm{MnO}_{2}$ prepared by different precursor anions.

Table 3. XPS Energy Spectra Analysis of $\mathrm{MnO}_{2}$ Prepared by Different Precursor Anions

\begin{tabular}{lcccc}
\hline & $\mathbf{M n O}_{2}-\mathbf{S O}_{4}{ }^{2-}$ & $\mathbf{M n O}_{2}-\mathbf{A C}^{-}$ & $\mathbf{M n O}_{2}-\mathbf{C l}^{-}$ & $\mathbf{M n O}_{2}-\mathrm{NO}^{3-}$ \\
\hline $\mathrm{Mn}^{3+}(\%)$ & 36.11 & 39.26 & 34.94 & 44.27 \\
$\mathrm{Mn}^{4+}(\%)$ & 63.89 & 60.74 & 65.06 & 55.73 \\
$\mathrm{Mn}^{3+} / \mathrm{Mn}^{4+}$ & 0.57 & 0.65 & 0.54 & 0.79 \\
$\mathrm{O}_{\text {ads }}(\%)$ & 24.65 & 20.99 & 24.76 & 29.24 \\
$\mathrm{O}_{\text {lat }}(\%)$ & 75.35 & 79.01 & 75.24 & 70.76 \\
$\mathrm{O}_{\text {ads }} / \mathrm{O}_{\text {lat }}$ & 0.32 & 0.27 & 0.33 & 0.41 \\
\hline
\end{tabular}

peaks in $\mathrm{Mn} 2 \mathrm{p}_{3 / 2}$, and the binder energy of the peak at $641.8 \mathrm{ev}$ and $643.3 \mathrm{ev}$ was attributed to $\mathrm{Mn}^{3+}$ and $\mathrm{Mn}^{4+}$, respectively. As was showed in Table 3, the $\mathrm{Mn}^{3+}$ relative content of $\mathrm{MnO}_{2}-\mathrm{NO}_{3}{ }^{-}$ was the highest at $44.27 \%$, the $\mathrm{Mn}^{3+}$ relative content of $\mathrm{MnO}_{2}-\mathrm{Cl}^{-}$, $\mathrm{nO}_{2}-\mathrm{SO}_{4}{ }^{2-}$ and $\mathrm{MnO}_{2}-\mathrm{AC}^{-}$was $34.94 \%, 36.11 \%$ and $39.26 \%$, respectively. Moreover, the $\mathrm{MnO}_{2}-\mathrm{NO}_{3}^{-}$catalyst had the highest molar ratio of $\mathrm{Mn}^{3+} / \mathrm{Mn}^{4+}$ on the surface. Therefore, $\mathrm{MnO}_{2}-\mathrm{NO}_{3}{ }^{-}$ had the most oxygen vacancy, which would promote the conversion of ozone to reactive oxygen species (ROS) and beneficial to the activation and migration of oxygen in the gas phase [33].

Furthermore, two types of surface oxygen species were identified according to the $\mathrm{O}$ 1s spectra in Fig. 4(b). The peaks were located at 529.6-529.8ev and 531.4-531.5ev corresponding to lattice oxygen $\left(\mathrm{O}_{\text {lat }}\right)$ and adsorbed oxygen $\left(\mathrm{O}_{\mathrm{ads}}\right)$, respectively [34]. $\mathrm{O}_{\text {lat }}$ was the oxygen in the crystal structure, and the different relative contents of $\mathrm{Mn}^{3+}$ and $\mathrm{Mn}^{4+}$ of the four catalysts led to the difference in the binding energy of lattice oxygen. The $\mathrm{O}_{\text {ads }}$ was the oxygen on the crystal surface, mainly including $\cdot \mathrm{OH}, \cdot \mathrm{O}^{-}, \cdot \mathrm{O}_{2}^{-}$and other active groups, which had an important impact on the catalytic performance of $\mathrm{MnO}_{2}$ [35]. The adsorbed oxygen had higher mobility than that of surface lattice oxygen, so adsorbed oxygen played more important role in oxidation reactions than lattice oxygen $[24,36]$. In this work, the $\mathrm{MnO}_{2}-\mathrm{NO}_{3}{ }^{-}$ catalyst contained the highest surface adsorbed oxygen ratio $\mathrm{O}_{\text {ads }} / \mathrm{O}_{\text {lat }}$ at 0.41 , which was corresponding to its highest content of active groups on its surface, and had the highest catalystic activities among four $\mathrm{MnO}_{2}$ catalysts.

\subsection{Morphology Formation of Catalyst}

The XPS energy spectra (wide sweep) of $\mathrm{MnO}_{2}$ prepared by different precursor anions $\left(\mathrm{NO}_{3}^{-}, \mathrm{AC}^{-}, \mathrm{SO}_{4}{ }^{2-}, \mathrm{Cl}^{-}\right)$were presented in Fig. 5. In terms of the $\mathrm{MnO}_{2}-\mathrm{SO}_{4}{ }^{2-}$ and $\mathrm{MnO}_{2}-\mathrm{Cl}^{-}$and $\mathrm{MnO}_{2}-\mathrm{NO}_{3}{ }^{-}$catalyst, they all contain the elements of $\mathrm{Mn}, \mathrm{O}$ and $\mathrm{C}$, but the $\mathrm{MnO}_{2}-\mathrm{AC}^{-}$ catalyst contains the elements of $\mathrm{K}, \mathrm{Mn}, \mathrm{O}$ and $\mathrm{C}$, and the difference is mainly related to the crystal type of the catalyst. From the above XRD results, it can be seen that the $\mathrm{MnO}_{2}-\mathrm{SO}_{4}{ }^{2-}$ and $\mathrm{MnO}_{2}-\mathrm{Cl}^{-}$ and $\mathrm{MnO}_{2}-\mathrm{NO}_{3}^{-}$are all $\beta-\mathrm{MnO}_{2}$ crystals, while the catalyst $\mathrm{MnO}_{2}-\mathrm{AC}$ is $\alpha-\mathrm{MnO}_{2}$.

$\alpha-\mathrm{MnO}_{2}$ is the most common crystalline form of manganese oxide, and the internal channel structure of $\alpha-\mathrm{MnO}_{2}$ is of [2×2] type and the basic structural unit is $\left[\mathrm{MnO}_{6}\right]$, which stacks in the form of hexagonal density. In the process of $\alpha-\mathrm{MnO}_{2}$ crystal formation, cations often enter into the pores due to its large channel radius, and the ion radius of $\mathrm{K}^{+}$is similar to the channel size of $\alpha-\mathrm{MnO}_{2}$ crystal, so $\mathrm{K}^{+}$can play the role of template in the synthesis of $\alpha-\mathrm{MnO}_{2}[37,38]$. Additionally, Studies had showed that appropriate $\mathrm{K}^{+}$concentration could stabilize the [2×2] tunnel structure of $\alpha$ $-\mathrm{MnO}_{2}$, and is a key factor in the formation of $\alpha-\mathrm{MnO}_{2}$ [39]. Therefore, the $\mathrm{MnO}_{2}-\mathrm{AC}$ containing $\mathrm{K}^{+}$is considered to be $\alpha-\mathrm{MnO}_{2}$. However, $\mathrm{H}^{+}$and $\mathrm{K}^{+}$have a competitive relationship for occupying the [2×2] tunnel site because of the proton exchange under the conditions of high acidity in this study [40]. The addition of weakly alkaline ion would lead to the decrease of $\mathrm{H}^{+}$concentration and $\mathrm{K}^{+}$dominates competition between $\mathrm{K}^{+}$and $\mathrm{H}^{+}$in the tunnel structure. The high concentration of $\mathrm{H}^{+}$will greatly reduce the chance of $\mathrm{K}^{+}$ 


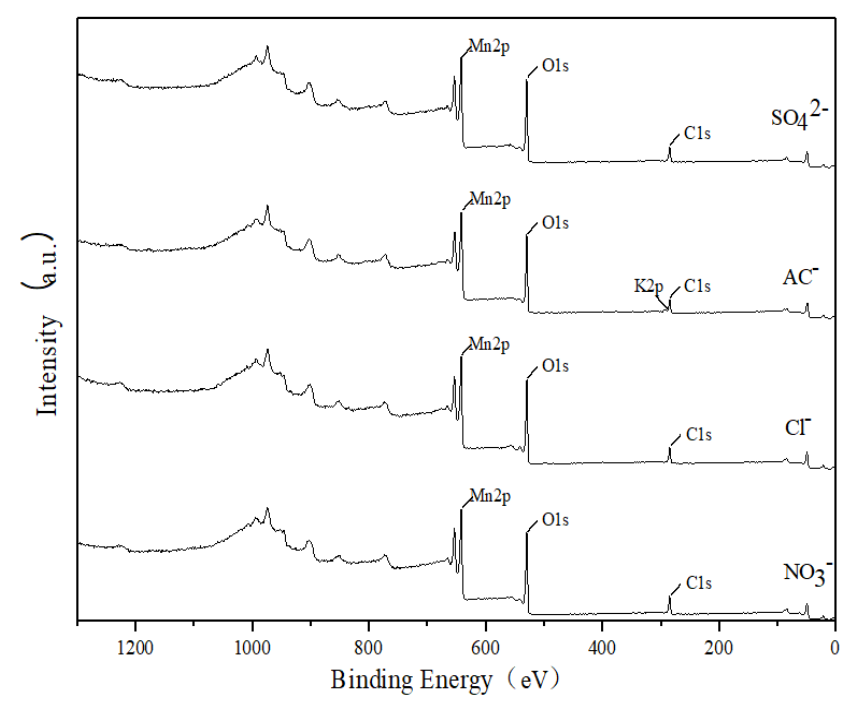

Fig. 5. XPS energy spectra (wide sweep) of $\mathrm{MnO}_{2}$ prepared by different precursor anions.

occupying the active site of [2×2] tunnel, therefore, the highly acidic conditions are conducive to the generation of [1×1] tunnel structure of $\mathrm{MnO}_{2}$, which might be the reason that the $\mathrm{MnO}_{2}-\mathrm{SO}_{4}{ }^{2-}$, $\mathrm{MnO}_{2}-\mathrm{Cl}^{-}$and $\mathrm{MnO}_{2}-\mathrm{NO}_{3}{ }^{-}$are $\beta$ crystal forms and the constituent elements do not contain $\mathrm{K}$ ions.

\subsection{1. $\mathrm{MnO}_{2}-\mathrm{AC}^{-}$}

According to the characterization analysis of XRD and XPS, $\mathrm{MnO}_{2}-\mathrm{AC}^{-}$is $\alpha-\mathrm{MnO}_{2}$ crystals. In addition, Fig 3 shows that the intensity of XRD diffraction peak of $\mathrm{MnO}_{2}-\mathrm{AC}^{-}$is weaker than that of $\mathrm{MnO}_{2}-\mathrm{SO}_{4}^{2-}$ and $\mathrm{MnO}_{2}-\mathrm{Cl}^{-}$. Studies have showed that the smaller the intensity of the diffraction peak, the weaker the crystallinity and the smaller the grain size, which is more conducive to the selective adsorption of some organic molecules [41]. This is why the catalytic activities of $\mathrm{MnO}_{2}-\mathrm{AC}^{-}$catalyst is stronger than that of $\mathrm{MnO}_{2}-\mathrm{SO}_{4}{ }^{2-}$ and $\mathrm{MnO}_{2}-\mathrm{Cl}^{-}$catalyst. However, the catalytic activities of $\mathrm{MnO}_{2}-\mathrm{AC}$ catalyst is weaker than that of $\mathrm{MnO}_{2}-\mathrm{NO}_{3}{ }^{-}$catalyst. The reason for this phenomenon may be that $\mathrm{AC}^{-}$, which has the largest ionic radius among the four anions, limits the diffusion rate of the precursors $\mathrm{Mn}^{2+}$ and $\mathrm{Mn}^{7+}$, and then results in a reduction in the redox reaction rate.

\subsection{2. $\mathrm{MnO}_{2}-\mathrm{Cl}^{-}$}

$\mathrm{MnO}_{2}-\mathrm{Cl}^{-}$halargest grain size among the three $\beta$ crystal catalysts. This might because the Stokes radius of $\mathrm{Cl}^{-}$was the smallest among the four precursor anions, and it could be uniformly adsorbed on the (110), (101), (111) and (211) crystal plane [42]. The presence of $\mathrm{Cl}^{-}$reduced the surface energy of the crystal plane, resulting in a low growth rate of the crystal plane, which ultimately led to a large exposed area of the crystal plane and a strong diffraction peak intensity. Therefore, $\mathrm{MnO}_{2}-\mathrm{Cl}^{-}$has the largest grain size, the best crystallinity and the fewest crystal defects. In addition, the $\mathrm{MnO}_{2}-\mathrm{Cl}^{-}$has the smallest specific surface area $\left(14.683 \mathrm{~m}^{2} / \mathrm{g}\right)$, the smallest pore volume $\left(0.0013 \mathrm{~cm}^{3} / \mathrm{g}\right)$ and a lowest ratio of $\mathrm{Mn}^{3+}$ $/ \mathrm{Mn}^{4+}(0.54)$. The above reasons result in poor catalytic performance of $\mathrm{MnO}_{2}-\mathrm{Cl}^{-}$.

\subsection{3. $\mathrm{MnO}_{2}-\mathrm{SO}_{4}{ }^{2-}$}

Among three $\beta$ crystal catalysts, the (110) crystal plane diffraction peak of $\mathrm{MnO}_{2}-\mathrm{SO}_{4}{ }^{2-}$ is widened. This phenomenon might be attributed to the fact that the $\mathrm{SO}_{4}{ }^{2-}$ ion has a large radius and can only preferentially adsorbed on the (111) crystal plane with the lowest $\mathrm{Mn}^{4+}$ density, and then the steric hindrance effect is formed [29]. Therefore, the growth of the crystal along the crystal plane is restricted, and the (110) crystal plane with higher $\mathrm{Mn}^{4+}$ density becomes the preferential growth plane, which eventually leads to the phenomenon of broadening the diffraction peak of the (110) crystal plane. In addition, the diffraction peak intensity of $\mathrm{MnO}_{2}-\mathrm{SO}_{4}{ }^{2-}$ is weaker than $\mathrm{MnO}_{2}-\mathrm{Cl}^{-}$but stronger than $\mathrm{MnO}_{2}-\mathrm{NO}_{3}{ }^{-}$. Therefore, $\mathrm{MnO}_{2}-\mathrm{SO}_{4}{ }^{2-}$ has low crystallinity and some crystal defects, which in turn show good catalytic activity. However, $\mathrm{SO}_{4}{ }^{2-}$ interacts with $\mathrm{Mn}^{2+}$ in the system, and its larger ionic radius reduces the diffusion rate of the reactants, thereby reducing the rate of product formation, so the product obtained is also less than that obtained under other conditions [43].

\subsection{4. $\mathrm{MnO}_{2}-\mathrm{NO}_{3}^{-}$}

The diffraction peak intensity of $\mathrm{MnO}_{2}-\mathrm{NO}_{3}{ }^{-}$was the weakest and the (110) crystal plane disappears. The above phenomenon indicates that $\mathrm{MnO}_{2}-\mathrm{NO}_{3}^{-}$has low crystallinity, imperfect crystal growth, and many crystal defects. Complementing this, the XPS characterization results indicate that the $\mathrm{MnO}_{2}-\mathrm{NO}_{3}{ }^{-}$has the highest ratio of $\mathrm{Mn}^{3+} / \mathrm{Mn}^{4+}(0.79)$ and the most oxygen vacancies. At the same time, XRD characterization shows that the average grain size of $\mathrm{MnO}_{2}-\mathrm{NO}_{3}{ }^{-}$is the smallest (11.9 nm), which leads to the smallest crystal plane spacing and grain gap. This will inevitably result in the largest specific surface area of the $\mathrm{MnO}_{2}-\mathrm{NO}_{3}{ }^{-}\left(132.303 \mathrm{~m}^{2} / \mathrm{g}\right)$, which is consistent with the BET characterization results. Also, XPS characterization shows that the surface of $\mathrm{MnO}_{2}-\mathrm{NO}_{3}^{-}$has more adsorbed oxygen (such as surface hydroxyl groups), and crystal defects can further promote the migration of adsorbed oxygen with a higher content of the catalyst surface, while the migration of adsorbed oxygen plays an important role in the decomposition and conversion of ozone, which ultimately affects the catalytic performance of the catalyst. So, $\mathrm{MnO}_{2}-\mathrm{NO}_{3}^{-}$exhibits the best catalytic activity.

\section{Conclusion}

Four $\mathrm{MnO}_{2}$ samples were prepared by the redox precipitation method using $\mathrm{KMnO}_{4}$ and various $\mathrm{Mn}^{2+}$ precursors for catalytic ozonation. The different anionic precursors forming structure form of $\mathrm{MnO}_{2}$ and its catalytic ozonation performance on simulated BTCW were studied. The results showed that anion precursors played a great role in controlling the morphology of the product $\mathrm{MnO}_{2}$, but it did not work in the catalytic performance. The surface chemical composition, content, specific surface area and crystal structure of four $\mathrm{MnO}_{2}$ materials prepared by different precursor anions $\left(\mathrm{NO}_{3}^{-}, \mathrm{AC}^{-}, \mathrm{SO}_{4}{ }^{2-}, \mathrm{Cl}^{-}\right)$were significantly different. Among them, $\mathrm{MnO}_{2}-\mathrm{NO}_{3}{ }^{-}$had the smallest average grain size, the largest crystal defect, the highest relative content of $\mathrm{Mn}^{3+}$, the most oxygen vacancy, the highest relative content of adsorbed oxygen $\left(\mathrm{O}_{\mathrm{ads}}\right)$, the most surface active groups and the largest specific surface 
area. The combined action of these factors finally improved the catalytic ozonation performance of $\mathrm{MnO}_{2}-\mathrm{NO}_{3}{ }^{-}$. After $2 \mathrm{~h}$ catalytic ozonation, the COD removal rates by $\mathrm{MnO}_{2}-\mathrm{NO}_{3}{ }^{-}$reached $47.39 \%$, which was $3.94 \%, 12.42 \%, 12.94 \%$ and $21.51 \%$ higher than that of $\mathrm{MnO}_{2}-\mathrm{AC}, \mathrm{MnO}_{2}-\mathrm{SO}_{4}{ }^{2-}, \mathrm{MnO}_{2}-\mathrm{Cl}^{-}$and pure $\mathrm{O}_{3}$ systems, respectively.

\section{Acknowledgment}

This study was supported by the Fundamental Research Funds for the Central Universiies (2019XKQYMS78) and China Postdoctoral Science Foundation (Grant No. 2019M650131).

\section{Author Contributions}

D.B. (M.D. student) and D.D. (M.D. student) conducted all the experiments and wrote the manuscript. Z.J. (Associate Professor) and G.SJ. (Associate Professor) wrote and revised the manuscript. H.SL. (Associate Professor) revised the manuscript.

\section{References}

1. Kosar HHA. Application of different advanced oxidation processes for the removal of chloroacetic acids using a planar falling film reactor. Chemosphere 2019a;228:377-383.

2. Pouretedal HR, Hasanali MA. Photocatalytic degradation of some beta-lactam antibiotics in aqueous suspension of $\mathrm{ZnS}$ nanoparticles Desalin. Water Treat. 2013;51:2617-2623.

3. Kosar Hikmat Hama Aziz, Omer KM, Mahyar A, Miessner H, Mueller S, Moeller D. Application of Photocatalytic Falling Film Reactor to Elucidate the Degradation Pathways of Pharmaceutical Diclofenac and Ibuprofen in Aqueous Solutions. Coatings 2019b;9:465-475.

4. Bello MM, Raman AAA, Asghar A. A review on approaches for addressing the limitations of Fenton oxidation for recalcitrant wastewater treatment. Process Saf. Environ. Prot 2019;126: 119-140.

5. Hien NT, Nguyen LH, Van HT, et al. Heterogeneous catalyst ozonation of Direct Black 22 from aqueous solution in the presence of metal slags originating from industrial solid wastes. Sep. Purif. Technol. 2020;233:115961.

6. Mousavi SMS, Dehghanzadeh R, Ebrahimi SM. Comparative analysis of ozonation (O3) and activated carbon catalyzed ozonation (ACCO) for destroying chlorophyll a and reducing dissolved organic carbon from a eutrophic water reservoir. Chem. Eng. J. 2017;314:396-405.

7. Iervolino G, Vaiano V, Palma V. Enhanced removal of water pollutants by dielectric barrier discharge non-thermal plasma reactor. Sep. Purif. Technol. 2019; 215:155-162.

8. Nawaz F, Xie YB, Cao HB, et al. Catalytic ozonation of 4-nitrophenol over an mesoporous $\alpha-\mathrm{MnO}_{2}$ with resistance to leaching. Catal. Today 2015;258:595-601.

9. Liu C, Chen XX, Zhang J, Zhou HZ, Zhang L, Guo YK. Advanced treatment of bio-treated coal chemical wastewater by a novel combination of microbubble catalytic ozonation and biological process. Sep. Purif. Technol. 2018;197:295-301.

10. Zhang, J, Xiong ZK, Wei J, et al. Catalytic ozonation of penicillin G using cerium-loaded natural zeolite (CZ): Efficacy, mechanisms, pathways and toxicity assessment. Chem. Eng. J. 2020;383:123144.

11. Tan XQ, Wan YF, Huang YJ, et al. Three-dimensional $\mathrm{MnO}_{2}$ porous hollow microspheres for enhanced activity as ozonation catalysts in degradation of bisphenol A. J. Hazard. Mater. 2017;321:162-172.

12. Niu Z, Yue T, Hu WJH, Sun W, Hu YH, Xu ZH. Covalent bonding of $\mathrm{MnO}_{2}$ onto graphene aerogel forwards: Efficiently catalytic degradation of organic wastewater. Appl. Surf. Sci. 2019;496:143585.

13. Zhang JL, Zhuang T, Liu SJ, Zhang GC, Huo KL. Catalytic ozonation of phenol enhanced by mesoporous $\mathrm{MnO}_{2}$ prepared through nanocasting method with SBA-15 as template. $J$. Environ. Chem. Eng. 2020; 8:103967.

14. Dong YM, Yang HX, He K, Song SQ, Zhang AM. $\beta-\mathrm{MnO}_{2}$ nanowires: a novel ozonation catalyst for water treatment. Appl. Catal. B. Environ. 2009;85:155-161.

15. Dua XG, Sun HQ, Wang YX, Kang J, Wang SB. N-doping-induced-nonradical reaction on single walled carbon nanotubes for catalytic phenoloxidation. ACS Catal. 2015;5:553-559.

16. Saputra E, Muhammad S, Sun HQ, Ang HM, Tadé MO, Wang SB. Manganese oxides at different oxidation states for heterogeneous activationof peroxymonosulfate for phenol degradation in aqueous solutions. Appl. Catal. B. Environ. 2013;142:729-735.

17. Yang Y, Huang J, Wang SW, Deng SB, Wang B, Yu G. Catalytic removal of gaseous unintentional POPs on manganese oxide octahedral molecular sieves. Appl. Catal. B. Environ. 2013;142-143:568-78.

18. Jiang Y, Cheng G, Yang RN, et al. Influence of preparation temperature and acid treatment on the catalytic activity of $\mathrm{MnO}_{2}$. J. Solid State Chem. 2019;272:173-81.

19. Jung HP, Dong CK, Sang JP, Chae HS. CO oxidation over $\mathrm{MnO}_{2}$ catalysts prepared by a simple redox method: Influence of the Mn (II) precursors. J. Ind. Eng. Chem. 2015;2525:250-257.

20. Hwang SC, Jo SH, Kim JH, et al. Catalytic activity of $\mathrm{MnOx} / \mathrm{TiO}_{2}$ catalysts synthesized with different manganese precursors for the selective catalytic reduction of nitrogen oxides. Reac. Kinet. Mech. Cat. 2016;117:583-591.

21. Yu YL, Li CT, Du XY, Zhu YC, Zhang, YD, Li SH. Catalytic oxidation of toluene over $\mathrm{MnO}_{2}$ catalysts with different $\mathrm{Mn}$ (II) precursors and the study of reaction pathway. Fuel 2020;262:116610.

22. Peña DA, Uphade BS, Smirniotis $\mathrm{PG}$. $\mathrm{TiO}_{2}$-supported metal oxide catalysts for low-temperature selective catalytic reduction of NO with NH3: I. Evaluation and characterization of first row transition metals. J. Catal. 2004;221(2):421-431.

23. Liu D, Wang CR, Song YF, et al. Effective mineralization of quinoline and bio-treated coking wastewater by catalytic ozonation using $\mathrm{CuFe}_{2} \mathrm{O}_{4} /$ Sepiolite catalyst: Efficiency and mechanism. Chemosphere 2019;227:647-656.

24. Liu FD, He H, Ding Y, Zhang CB. Effect of manganese substitution on the structure and activity of iron titanate catalyst for the selective catalytic reduction of $\mathrm{NO}$ with $\mathrm{NH}_{3}$. Appl. Catal. 
B-Environ. 2009;39:194-204.

25. Zhang FZ, Wei CH, Hu Y, Wu HZ. Zinc ferrite catalysts for ozonation of aqueous organic contaminants: phenol and bio-treated coking wastewater. Sep. Purif. Technol. 2015;156: 625-635.

26. Hao BY, Sun YG, Shen Q, Zhang X, Zhang ZS. Insight into structure defects and catalytic mechanism for NO oxidation over Ce0.6Mn0.4Ox solid solutions catalysts: Effect of manganese precursors. Chemosphere 2020;243:125406.

27. Prasad DH, Park SY, Ji HI, et al. Structural characterization and catalytic activity of Ce0.65Zr0.25RE0.1O2- $\delta$ nanocrystalline powders synthesized by the glycine-nitrate process. J Phys. Chem. C. 2012;116: 3467-3476.

28. Zou F, Jiang Z, Qin XQ, et al. Template-free synthesis of mesoporous N-doped $\mathrm{SrTiO}_{3}$ perovskite with high visible-light-driven photocatalytic activity. Chem. Commun. 2012;48(68):85148516.

29. Yin BS, Zhang SW, Jiang H, Qu FY, Wu X. Phase-controlled synthesis of polymorphic $\mathrm{MnO}_{2}$ structures for electrochemical energy storage. J. Mater. Cchem. A. 2015;3(10):5722-5729.

30. $\mathrm{Xu} \mathrm{H}$, Tong SY. Interaction of $\mathrm{O}_{2}$ with reduced rutile $\mathrm{TiO}_{2}$ (110) surface. Surf. Sci. 2013;610:33-41.

31. Hao BY, Sun YG, Shen Q, Zhang X, Zhang ZS. Insight into structure defects and catalytic mechanism for $\mathrm{NO}$ oxidation over $\mathrm{Ce}_{0.6} \mathrm{Mn}_{0.4} \mathrm{O}_{x}$ solid solutions catalysts: Effect of manganese precursors. Chemosphere 2020;243:125406.

32. Hou JT, Li YZ, Mao MY, Ren L, Zhao XJ. Tremendous Effect of the Morphology of Birnessite-Type Manganese Oxide Nanostructures on Catalytic Activity. ACS Appl. Mater. Interfaces. 2014;6(17):14981-14987.

33. Ren YM, Dong Q, Feng J, Ma J, Wen Q, Zhang M. Magnetic porous ferrospinel $\mathrm{NiFe}_{2} \mathrm{O}_{4}$ : A novel ozonation catalyst with strong catalytic property for degradation of di-n-butyl phthalate and convenient separation from water. J. Colloid. Interface Sci.
2012;382(1):90-96.

34. Xu P, Wu ZX, Deng JG, et al. Catalytic performance enhancement by alloying $\mathrm{Pd}$ with $\mathrm{Pt}$ on ordered mesoporous manganese oxide for methane combustion. Chinese J. Catal. 2017;38(1):92-105.

35. Arandiyan H, Dai HX, Deng JG, et al. Three-dimensionally ordered macroporous $\mathrm{La}_{0.6} \mathrm{Sr}_{0.4} \mathrm{MnO}_{3}$ with high surface areas: Active catalysts for the combustion of methane. J. Catal. 2013; 307:327-339.

36. Wu ZB, Jin RB, Liu Y, Wang HQ. Ceria modifified $\mathrm{MnOx} / \mathrm{TiO}_{2}$ as a superior catalyst for $\mathrm{NO}$ reduction with $\mathrm{NH}_{3}$ at low-temperature. Catal Commun. 2008;9:2217-2220.

37. Zhai DY, Li BH, Xu CJ, et al. A study on charge storage mechanism of $\alpha-\mathrm{MnO}_{2}$ by occupying tunnels with metal cations $\left(\mathrm{Ba}^{2+}, \mathrm{K}^{+}\right)$. J. Power Sour. 2011;196(18):7860-7867.

38. Poyraz AS, Huang JP, Pelliccione CJ, et al. Synthesis of cryptomelane type $\alpha$-MnO2 $\left(\mathrm{K}_{\mathrm{x}} \mathrm{Mn}_{8} \mathrm{O}_{16}\right)$ cathode materials with tunable $\mathrm{K}^{+}$content: the role of tunnel cation concentration on electrochemistry. J. Mater. Chem. A. 2017;5(32):16914-16928.

39. Ding YS, Shen XF, Sithambaram S, et al. Synthesis and Catalytic Activity of Cryptomelane-Type Manganese Dioxide Nanomaterials Produced by a Novel Solvent-Free Method. Chem. Mater. 2005;17(21):5382-5389.

40. Huang XK. Synthesis, Structural Characterization of Manganese Dioxide and Their Electrochemical Performances. [dissertation]. China: Xiamen University. 2017.

41. Xu QS, Zhu YJ, Zhao RD, Han QY, ZhuangYH, Zeng YT. Effect of Preparation Conditions on the Phase of $\mathrm{Ni}(\mathrm{OH})_{2}$ (in chinese). J. Synthetic Crystals 20102;41(05):1232-1236.

42. Yin XL. Sythesis of low temperature and high active $\alpha-\mathrm{MnO}_{2}$ and the study of catalytic combustion performance [dissertation]. China: Hebei Normal University. 2013.

43. Gui YC, Qian LW, Qian XF. Nanometer $\mathrm{MnO}_{2}$ : Hydrothermal Synthesis and Effect of Salt Modifiers on Polymorph \& Morphology. Chinese J. Inorg. Chem. 2009;25(4):668-673. 